\title{
STRATEGI KEBIJAKAN PENGEMBANGAN SUMBER DAYA APARATUR PEMERINTAH DAERAH KABUPATEN SIDENRENG RAPPANG
}

\author{
Syamsul Sunusi \\ Fakultas Ilmu Sosial, Universitas Negeri Makassar
}

\begin{abstract}
ABSTRAK
Strategi kebijakan pendidikan dan pelatihan aparatur pemerintah daerah pada dasarnya bertujuan untuk meningkatkan pengetahuan, keterampilan/keahlian dan kemahiran dalam melaksanakan berbagai tugas dan pekerjaan yang dibebankan kepada aparatur dan perubahan sikap mental kejuangan aparatur pemerintah daerah dalam melakukan pelayanan public yang baik kepada masyarakat.Strategi Kebijakan pengembangan sumberdaya aparatur pemerintah daerah melalui pendidikan dan pelatihan ketika tidak disertai dengan perencanaan yang komprenhensif, makatidak akan mendukung tingkat kompetensi yang tepat dalam rangka untuk menjamin efektifitas dan efisiensi organisasi, dan juga mengakibatkan implementasi tentang kebijakan perecanaan karier, dan pengembangan karier aparatur pemerintah daerah beberapa kriteria model ideal birokrasi diabaikan. Seperti pengaturan penempatan didasarkan atas kemampuan aparatur, terpenuhinya syarat rekam jejak karier aparatur, dan hubungan organisasi yang bersifat resmi bukan pribadi.
\end{abstract}

Kata kunci: Kebijakan, Pengembangan Sumber Daya Aparatur, Pemerintah Daerah.

\section{PENDAHULUAN}

Salah satu yang populer di media imformasi public saat ini adalah menyangkut rendahnya kualitas Sumber Daya Manusia di lembaga pemerintah juga dapat diindikasikan dari kinerja Pegawai Negeri Sipil. Seperti halnya Azhar Kasim (2007) bahwa dalam kenyataannya kompetensi dan produktivitas aparatur masih rendah, dan perilaku yang sangat rule driven, paternalistik, dan kurang professional dibidang tugas dan pekerjaan..

Sejalan dengan itu kebijakan mengenai pengembangan sumberdaya aparatur Negara, menurut Rosidah (2008), dalam jurnal kebijakan dan administrasi publik, melalui pendidikan dan pelatihan, aparatur diharapkan dapat memperoleh pengetahuan, keterampilan, dan keahlian, menelusuri jenjang karier serta untuk meningkatkan efektifitas, derajat professionalisme penyelenggaraan tugas yang nantinya dapat diterapkan dalam bekerja maupun dalam rangka pengembangan organisasi.

Berdasarkan hasil obserfasi yang dilakukan peneliti dikantor pemerintah daerah kabupaten Sidrap menunjukkan belum nampak kesempurnaan dalam pelaksanaan pelatihan dan pengembangan sumber daya aparatur baik dari sudut ketidak samaan pelaksanaan dengan "policy guidelines" maupun minimnya hasil yang dicapai. Dalam banyak hal "Pengembangan sumber daya aparatur tidak selalu didasarkan pada kebutuhan, dilakukan kurang professional dan tidak berkesinam-bungan "Implementasi kebijakan pendidikan dan pelatihan belum sepenuhnya dapat terwujud karena masih 
terdapatnya kelemahan-kelemahan dalam pelaksanaannya.

Kultur Pemerintah Daerah Kabupaten Sidrap masih didominasi oleh kultur yang berorientasi pada status dari pada prestasi kerja, sehingga mengakibatkan pola karier sumber daya aparatur pemerintah lebih mengakomodir kepada kuantitas dan status dari pada kompetensi, kualitas, dan prestasi kerja. Seharusnya konsep pola karier sumber daya aparatur harus mengakomodasi dengan baik klasifikasi jabatan dan standar kompetensi sumber daya aparatur sehingga berpengaruh pada pencapaian kinerja organisasi dan individu yang optimal (Keban, 2008).

Pada sisi lain, pelayanan publik dalam pelaksanaan birokrasi pemerintah daerah kabupaten Sidrap masih belum secara kondisional melaksanakan prinsipprinsip pelayanan yang memuaskan masyarakat. Hal ini disebabkan karena pola atau jenjang karir aparatur tidak terlaksana sesuai aturan perundangundangan yang berlaku.

Terkait dengan otonomi daerah, sumber daya aparatur pemerintah di tuntut untuk cerdas dan tanggap mengakomodir tuntutan, harapan, dan kebutuhan masyarakat sesuai dengan prinsip-prinsip good governace, sehingga aparatur menjunjung tinggi keinginan atau kehendak masyarakat dan aspek fungsional dari pemerintahan efektif dan efisien dalam pelaksanaan tugasnya.

\section{KAJIAN TEORI}

\section{Strategi kebijakan}

Menurut Robbins (1994:134) strategi dapat didefinisikan sebagai penentuan dari tujuan, dasar jangka panjang, sasaran sebuah perusahaan atau instansi, dan penerimaan dari serangkaian tindakan, serta alokasi dari sumber-sumber yang dibutuhkan untuk melaksanakan tujuan tersebut. Sedangkan Mc Nichols dalam Salusu (2005:85), memandang bahwa strategis ialah suatu seni menggunakan kecakapan dan sumberdaya suatu organisasi untuk mencapai sasarannya melalui hubungan yang efektif dengan lingkungan dalam kondisi yang paling menguntungkan.

\section{Pendidikan dan Pelatihan}

Menurut Peraturan Pemerintah No.101 tahun 2000 bahwa Pelatihan merupakan proses pendidikan jangka pendek bagi pegawai operasional untuk memperoleh ketrampilan operasional sistematis. Sedangkan pendidikan dan pelatihan akan memberikan bantuan pada masa yang akan datang dengan jalan pengembangan pola pikir dan bertindak, terampil berpengetahuan dan mempunyai sikap serta pengertian yang tepat untuk pelaksanaan pekerjaan.

\section{Pembinaan Karier}

Karier adalah perjalanan yang dilalui seseorang selama hidupnya. Menurut Handoko (2000:123), karier dimaksudkan semua pekerjaan atau jabatan yang ditangani atau dipegang selama kehidupan kerja seseorang aparatur. Dengan demikian karier menunjukkan perkembangan para pegawai secara individual dalam jenjang jabatan atau kepangkatan yang dapat dicapai selama masa kerja dalam suatu organisasi.

Menurut Daniel C. Feldam dan Hugh J. Arnold dalam Moekijat, (1995: 4-5). Istilah karier tidak hanya berhubungan dengan individu yang mempunyai pekerjaan yang status lebih tinggi atau yang mendapat kemajuan status lebih cepat. Istilah karier sedikit banyak telah "didemokratisasi: karier menunjukkan rangkaian atau urutan pekerjaan/jabatan yang dipegang oleh aparatur selama riwayat pekerjaannya, tidak pandang tingkat pekerjaan atau tingkat organisasinya. Pejabat atau pimpinan dan sekretaris pejabat pimpinan akan ditentukan gerakan karier vertical dan gerakan karier horizontal. 


\section{Pengembangan karier}

Pengembangan karier (promosi) sangat diharapkan oleh setiap pegawai, karena dengan pengembangan akan mendapatkan hak - hak yang lebih baik material maupun non material misalnya, kenaikan pendapatan, perbaikan fasilitas dan sebagainya. Sedangkan hak-hak yang tidak bersifat material misalnya status sosial, perasaan bangga dan sebagainya. Dalam praktek pengembangan karier lebih merupakan suatu pelaksanaan rencana karier seperti yang diungkapkan oleh Handoko (2000: 123) bahwa pengembangan karier adalah peningkatan pribadi yang dilakukan seorang aparatur untuk mencapai suatu rencana karier.

\section{Model Birokrasi Ideal}

Model birokrasi Weberian digagas oleh Max Weber, dalam Toha (2007:18) seorang tokoh penting yang menjelaskan konsep birokrasi menunjuk pada model birokrasi yang memfungsikan birokrasi sehingga memenuhi kriteria-kriteria ideal birokrasi, yaitu: Pengambilan keputusan mengenai penempatan pegawai yang didasarkan atas kemampuan; Jejak karier bagi para pegawai; Kehidupan organisasi yang dipisahkan dengan jelas dari kehidupan pribadi.

\section{METODE PENELITIAN}

Jenis penelitian kualitatif, Obyek penelitian Aparatur Pemerintah Daerah, imforman kunci, imforman ahli, dan imforman pendamping,Teknik pengumpulan data observasi, wawancara mendalam, kecukupan referensi, pencermatan pengamatan. Pengabsahan data Perpanjangan keikutsertaan, ketekunan pengamatan dan trianggulasi. Teknik analisis data kategorisasi. Lokasi Penelitian Kantor bupati Sidenreng Rappang khususnya pada Badan Kepegawaian Daerah Kabupaten Sidenreng Rappang.
Fokus Penelitian adalah Strategi kebijakan Pengembangan aparatur Pemerintah aparatur yang telah mengikuti Pendidikan dan Pelatihan. Hal ini merupakan serangkaian langkah aparatur yang memberikan sumbangan pada penempatan jabatan atau posisinya sesuai dengan kompetensi dan spesealisasi aparatur Pemerintah daerah yang relevan dengan teori Max Weber dalam Keban (2008:158) dan sesuai Surat Keputusan Pemerintah Nomor. 101 Tahun 2000.

\section{HASIL DAN PEMBAHASAN}

\section{Strategi Kebijakan Pengembangan}

Untuk mengantisipasi dampak negatif pelayanan publik aparatur pemerintah daerah kabupaten Sidenreng Rappang yang semakin berlarut-larut, maka diperlukan upaya dan strategi pengembangan sumber daya Aparatur yang tepat, efektif dan efisien serta applicable. Pembaharuan ini dimungkinkan sejalan dengan semangat Undang-Undang Nomor. 32 Tahun 2004 yang menempatkan pemerintah kabupaten/kota untuk lebih mandiri mengelola sumber daya aparatur yang dimiliki,sejalan dengan kebijakan pemerintahan yang baik.

Dalam memainkan peranan seorang penentu kebijakan pada saat ini adalah memasukkan kompetensi aparatur organisasi yang sesuai dengan peluang serta resiko yang diciptakan oleh perubahan lingkungan. Fungsi kebijakan stratejik yang terpenting adalah mengarahkan pemikiran dan tindakan seluruh lapisan masyarakat dalam Negara dan bangsa menujuh kearah yang lebih baik. Strategi yang dimaksud dalam penelitian ini adalah:

\section{Pendidikan Pelatihan}

Salah satu kebajikan pokok dari pendidikan dan pelatihan, adalah bertujan menciptakan aparatur yang mampu berperan sebagai pembaharu dan perekat 
persatuan dan kesatuan bangsa, Pada sisi lain memantapkan sikap dan semangat pengabdian berorientasi pada pelayanan dan pengayoman dan pemberdayaan masyarakat, menciptakan kesamaan visi dan dinamika pola pikir dalam melaksanakan tugas pemerintahan umum dan pembangunan demi terwujudnya pemerintahan yang baik.

Dalam kaitan dengan pengembangan sumber daya aparatur pada Kantor Badan Kepegawian Daerah merujuk pada Peraturan Pemerintah No. 101 Tahun 2000, Tentang Pendidikan dan Pelatihan Jabatan Pegawai Negeri Sipil adalah: (1) Pendidikan dan pelatihan Prajabatan adalah pedidikan yang diberikan kepada calon Pegawai Negeri Sipil bersifat pembekalan, agar mereka dapat memahami tugas-tugas yang nantinya dibebankan kepada mereka, (2) Pendidikan dan pelatihan dalam jabatan terdiri dari: (a) Pendidikan dan pelatihan Kepemimpinan adalah Pendidikan dan pelatihan yang dirancang untuk memenuhi kompetensi yang dibutuhkan pegawai negeri sipil dalam jabatan sturuktural dengan jenjang eselon yang telah dipangkunya seperti Pendidikan dan pelatihan pimpinan tingkat IV, Pendidikan dan pelatihan Pimpinan tingkat III, Pendidikan dan pelatihanpimpinan tingkat II, dan Pendidikan dan pelatihan Pimpinan tingkat I, (b) Pendidikan dan pelatihan Fungsional adalah untuk memenuhi persyaratan kompetensi tertentu yang sesuai dengan fungsinya, dan (c) Pendidikan dan pelatihan Teknis adalah untuk memberikan ketrampilan bagi Pegawai Negeri Sipil yang berhubungan langsung dengan pelaksanaan tugas pokok instansi.

Berdasarkan data tahun 2010-2012 jumlah keseluruhan pegawai dilingkungan Pemerintah Daerah Kabupaten Sidrap Sulawesi Selatan Republik Indonesia sebanyak 6.997 orang. Jumlah pegawai yang telah mengikuti pedidikan dan pelatihan sebanyak 962 orang, kalau dipersepsikan hanya $7,2 \%$ yang telah selesai mengikuti Diklat.Masih kurangnya sumberdaya aparatur yang telah mengikuti Pendidikan dan pelatihan kedinasan sehingga mengakibatkan terjadinya kesenjangan (Gap) antara ketentuan jabatan dengan kemampuan yang dimiliki aparatur dan juga berarti Diklat Pegawai Negeri Sipil belum optimal dalam meningkatkan kompetensi aparatur pemerintah daerah. terpadu dan berkelanjutan, pembentukan komitmen dan daya tanggap serta pembentukan team dalam kerangka pengembangan kapabilitas aparatur pemerintah daerah, antara lain adalah dengan upaya pengembangan sumberdaya manusia aparat pemerintah daerah untuk mendapatkan kemampuan aparatur secara optimal. Peluang dan kesempatan untuk memperoleh pendidikan dan pelatihan baik secara formal maupun non formal dibuka lebar-lebar, kemudian pada akhirnya diberdayakan secara profesional dalam arti pendidikan yang telah diperoleh diberikan kesempatan untuk dapat diaplikasikan dalam ketugasannya.

Apabila diterapkan pada tujuan Diklat dalam Peraturan Pemerintah No. 101/2000, sudah sangat komplit dan menyeluruh meliputi aspek kognitif, afektif dan psikomotorik, aplikasinya terhadap masyarakat serta semangat nasionalisme aparatur tercapai. Apabila kita resapi tugas dalam pencapaian tujuan diklat tersebut cukup berat untuk mencapainya, tapi sikap optimistis dan positif thinking perlu ditumbuh kembangkan dalam setiap proses pengembangan sumberdaya manusia aparatur, paling tidak tahapan-tahapan serta proses yang mengarah kepada proses pengembangan kapasitas aparatur pemerintah daerah harus dilalui dengan dukungan kebijakan top manajer sehingga kejelasan arah dan tujuan didapatkan dan dapat dijadikan pegangan bagi setiap aparatur pemerintah daerah untuk dapat saling berkompetisi secara positif yang kemudian mengarah kepada kolaborasi team. Sikap merasa menjadi pahlawan, konseptor tunggal, sumber inspirasi dan 
lain sebagainya, yang pada intinya berupaya menunjukkan keberadaan secara individual harus dihindari.

Faktor yang tidak kala penting juga kinerja harus diyakini sebagai hasil dari kebersamaan sebagai wujud nyata dari satu team. Teknologi informasi (TI) memegang peranan yang penting dalam pengembangan kapasitas aparatur pemerintah daerah.Teknologi tersebut mutlak harus dikuasai oleh setiap aparatur pemerintah daerah yang berkeinginan untuk melangkah maju serta profesional. Tuntutan masyarakat mendapatkan proses pelayanan secara cepat dan tepat memerlukan tindak lanjut secara nyata yaitu komputerisasi dalam setiap kegiatan penyediaan jasa layanan. Pemusatan pemikiran dalam proses pembangunan yang selalu berorientasi kepada pengembangan teknologi khususnya teknologi informasi harus tetap berorientasi pada keinginan masyarakat atau pelanggan yang memerlukan data, informasi, pelayanan perizinan, kesehatan, maupun jasa pelayanan lainnya dengan akses yang mudah, tidak berbelit-belit, aman, efisien, adil, terbuka, cepat dan akurat.

Dengan adanya otonomi daerah berakibat pada bentuk kelembagaaan organisasi di tiap-tiap daerah menjadi berbeda-beda, penataan kelembagaan adalah inti dari suatu organisasi, kalau bentuk organisasi beserta tata laksananya sudah tidak karuan tentu akan berimplikasi pada proses penyelenggaraan pemerintahan yang ada. Kelembagaan yang terbentuk dalam organisasi pemerintah daerah diharapkan merupakan refleksi dari kebutuhan masyarakat setempat serta dapat mewadahi sumberdaya manusia aparatur yang ada secara profesional, tepat dalam penempatan sesuai bakat, minat dan profesi dasar yang telah mereka pelajari dalam lembaga formal serta pengalaman yang mereka dapatkan secara non formal. Motivasi dalam bekerja akan bangkit apabila mereka dihargai dan diakui pendidikan yang telah mereka tempuh dengan susah payah lalu diberdayakan oleh instansi dimana aparatur tersebut ditempatkan secara tepat, the right man in the right place.

Sementara itu decision maker dalam kebijakannya diharapkan dapat memberikan ruang atau skala prioritas pertama dalam hal pengembangan sumber daya manusia aparatur maupun sumber daya manusia yang ada di wilayah pemerintah daerah setempat. Fakta, realitas serta data menjadi landasan utama dalam setiap pengambilan kebijakan, dan sudah menjadi kenyataan bahwa dunia pendidikan dan pelatihan Sumber daya aparatur yang terabaikan akan berakibat krisis multidimensional yang belum juga kunjung reda sampai pada saat ini masih dialami oleh Bangsa Indonesia, dalam dunia pendidikan harus diakui kita semakin tertinggal dari dunia internasional. Maju tidaknya suatu wilayah sangat ditentukan oleh mutu serta kualitas Sumber daya aparatur yang dimiliki. Pola pikir global, kepercayaan dan toleransi menjadi falsafah utama dalam pengembangan Sumber daya aparatur harus mempunyai keahlian yang dapat dipergunakan pada setiap daerah bahkan bersifat mendunia. Setiap konsep maupun pendapat diberikan kesempatan serta kepercayaan untuk dapat dipertanggungjawabkan, apabila ada sinyal positif dalam setiap gagasan yang diajukan harus terus diberikan tantangan, dihargai, didorong, dimotivasi serta dijanjikan kompensasi yang kompetitif, pola pengembangan karir yang jelas, sarana kesehatan, keamanan kerja dan pemenuhan keperluan hidup yang optimal sesuai dengan kapasitas pemerintah daerah.

Harus diakui bahwa terlaksananya pengembangan kapasitas aparatur ini pemerintah daerah secara umum diharapkan dapat menciptakan aparatur pemerintah yang mempunyai kemampuan, kepekaan dan antisipatif terhadap perubahan yang terjadi, tertingkatkannya kemampuan dalam mengambil tindakan yang cepat, tepat dan akuntabel terhadap 
permasalahan yang muncul. Serta teroptimalkannya fungsi instansi dalam memberikan pelayanan publik. Apabila hal-hal tersebut di atas dapat terpenuhi dengan landasan komitmen bersama untuk introspeksi diri kemudian melakukan perubahan segera, maka tidak mustahil masyarakat sejahtera adil dan makmur yang sementara ini hanya sebatas visi saja akan segera dapat tercapai.

\section{Pembinaan Karier}

Adapun deskripsi system pembinaan karier menurut Winarso \& Ratminto dalam jurnal sistim pembinaan karier pemerintah. Bahwa penyusunan sistim pembinaan karier adalah: (1) Jabatan karir yang dikembangkan adalah berdasarkan pada kompetensi. Artinya pertimbangan utama dalam sekali penempatan pegawai pada jabatan tertentu adalah pada kompetensi pegawai tersebut. (2) Kesempatan untuk meniti karir harus memperhatikan kesetaraan gender. (3) Memenuhi syarat jabatan sebagaimana yang dirumuskan dari hasil analisis jabatan. Hal ini relevan dengan gagasan Max Weber dalam Thoha (2007:18) bahwa: Type ideal birokrasi adalah suatu birokrasi yang mempunyai suatu bentuk yang pasti dimana semua fungsi dijalakan dalam cara-cara rasional, setiap pejabat diseleksi atas dasar kualifikasi professionalitas, idealnya setiap pejabat yang ingin diangkat dilakukan melalui ujian kompetitif.

Ada juga Peraturan Pemerintah Republik Indonesia No.101 Tahun 2000 bahwa tanggung jawab, wewenang dan hak seseorang pegawai negeri sipil dalam fungsional rangka memimpin suatu organisasi negara. Sedangkan pengertian jabatan pegawai negeri sipil menurut Peraturan Pemerintah No.16 Tahun 1994 adalah kedudukan yang menunjukan tugas, tanggung jawab, wewenang dan hak seseorang pegawai negeri sipil dalam suatu organisasi dalam melaksanakan tugasnya didasarkan pada keahlian tertentu yang bersifat mandiri.
Terkait dengan jabatan Sturuktural atau jabatan eselon, di Kabupaten Sidenreng Rappang terdapat 963 jabatan struktural atau pejabat eselon yang terdiri dari pejabat sturuktural eselon V sampai dengan pejabat sturuktural eselon II. Pejabat eselon II-a adalah jabatan eselon tertinggi yaitu jabatan Sekretaris Daerah, yang paling banyak adalah jabatan struktural eselon IV-a yang jumlahnya ada 479 jabatan. Dan yang perlu dicatat, sampai dengan akhir bulan April 2012, ternyata di Kabupaten Sidenreng Rappang masih ada jabatan sturuktural eselon V, yang jumlahnya mencapai 43 jabatan.

Tabel 1

Rekapitulasi Data Jumlah Jabatan Eselon/Jabatan Sturuktural

\begin{tabular}{|l|l|c|}
\hline No & Jenis Eselon & Jumlah \\
\hline 1 & Eselon II-a & 1 \\
2 & Eselon II-b & 32 \\
3 & Eselon III-a & 57 \\
4 & Eselon III-b & 94 \\
5 & Eselon IV-a & 479 \\
6 & Eselon IV-b & 257 \\
7 & Eselon V & 43 \\
\hline \multicolumn{4}{|c|}{ Jumlah } & 963 \\
\hline \multicolumn{2}{|l}{ Sumber: } & Sistem Informasi Pegawai Badan \\
\multicolumn{4}{|c|}{ Kepegawaian Daerah }
\end{tabular}

Fokus peranan pembinaan sumberdaya aparatur hendaknya melalui langkah strategis agar penempatan aparatur sesuai dengan disiplin ilmu dan keahliannya.Hal ini dimaksudkan untuk menghindari diskriminasi yang menyebabkan sakit hati dan frustrasi aparatur yang kecewa.

Hal ini relevan dengan gagasan Max Weber dalam Thoha (2007:18) bahwa: Type ideal birokrasi adalah suatu birokrasi yang mempunyai suatu bentuk yang pasti dimana semua fungsi dijalakan dalam caracara rasional, setiap pejabat diseleksi atas dasar kualifikasi professionalitas, idealnya setiap pejabat yang ingin diangkat dilakukan melalui ujian kompetitif.

Meski demikian pembinaan terhadap Sumber daya manusia aparatur daerah 
adalah hal penting dalam meningkatkan kinerja organisasi pemerintahan, kinerja pelayanan kepada masyarakat (public servant), serta kinerja aparatur pemerintah itu sendiri dalam rangka mencapai visi dan misi serta tujuan daerah. Penataan pola karier aparatur adalah salah satu upaya yang dapat mewujudkan hal tersebut dengan disertai pengawalan penyelenggaraannya. Agar penerapan serta pelaksanaan penataan pola karier aparatur didaerah berlangsung sesuai dengan track/ jalurnya, maka perlu dilakukan perubahan pada penentuan pejabat pembina kepegawaian yang sebaiknya dipegang oleh aparatur yang menduduki jabatan karier tertinggi, bukan pada pejabat politis seperti yang terjadi sekarang, karena cenderung pejabat politis tersebut belum memahami kondisi kepegawaian serta aturan-aturan yang berkaitan dengan bidang kepegawaian, sehingga menimbulkan berbagai macam masalah di daerah termasuk pada keberlangsungan karier aparatur.

\section{Pengembangan Aparatur}

Isu yang sangat populer saat ini di daerah ialah menempatkan orang yang tidak sesuai dengan kompetensinya. Hal ini disebabkan oleh kurangnya aparatur yang memiliki kompetensi yang sesuai, dan karena masalah suka-tidak suka (like and dislike), Dalam kaitan dengan promosi jabatan pendapat" Peter Principle" dalam sedarmayanti (2007) bahwa aparatur akan mengalami penurunan tingkat kecerdasan ketika akan ia mendapat kesempatan promosi. Artinya semakin orang dipromosikan ke dalam jabatan yang lebih tinggi, maka semakin rendah tingkat kompetensinya.Hal ini sangat masuk akal, karena pengangkatan pertama dalam suatu jabatan tergantung pada kompetensinya,dan rekam jejak karier, yang dipersyaratkan oleh jabatan tersebut. Bila aparatur menduduki suatu jabatan baru yang lebih tinggi atau dimutasi, kompetensi tersebut tentu tidak cocok lagi baik dalam jenis maupun dalam tingkatan dan rumpun jabatan tersebut.

Berdasarkan data Sub Bidang Pendidikan dan Pelatihan Badan Kepegawaian Daerah Kabuapaten Sidrap terlihat pada tabel dibawah ini:

\section{Tabel 2.}

Rekapitulasi Aparatur Pemerintah Daerah yang Belum Mengikuti Pendidikan dan Pelatihan.

\begin{tabular}{|c|c|c|}
\hline Noo & $\begin{array}{c}\text { Jenis Pendidikan dan } \\
\text { pelatihan (Diklat) }\end{array}$ & $\begin{array}{l}\text { Jumlah } \\
\text { orang }\end{array}$ \\
\hline 1. & Diklat Pimpinan Tingkat II & 17 orang \\
\hline 2. & Diklat Pimpinan Tingkat III & 52 orang \\
\hline \multirow[t]{2}{*}{3.} & Diklt Pimpinan Tingkat IV & 370 orang \\
\hline & Jumlah & 439 orang \\
\hline
\end{tabular}

Sumber: Data Sistem Informasi Pegawai Badan Kepegawaian Daerah

Tabel 2 menunjukkan bahwa pelaksananan pendidikan pelatihan tidak direncanakan dengan baik dan tidak berkesinambungan. karena jumlahnya jabatan eselon yang ada sebanyak 963 orang, dan yang belum mengikuti diklat sebanyak 439 orang, dan semuanya telah menduduki jabatan sturuktural, sehinga dengan demikian aparatur tersebut bekerja tidak sesuai dengan peraturan pemerintah Republik Indonesia No. 101 tahun 2000. Artinya jabatan yang diemban aparatur tersebut tidak sesuai dengan kompetensinya.

Sesuai pengungkapan Helber Spencer (Martin,1989) dalam Keban (2008:22), bahwa sosok administrator publik adalah orang-orang pilihan artinya ia menduduki jabatan atas dasar kompetisi, bukan atas dasar kepangkatan atau kepercayaan semata. Dengan kompetisi maka yang dipilih adalah yang lebih baik dari lawan-lawannya yang juga menginginkan jabatan tersebut. Dengan kata lain sperioritas orang tersebut harus nampak. Karena itu dengan demikian masyarakat akan dipimpin oleh tokohtokoh terbaik.

Ketika diresapi atas pencapaian tujuan pengembangan aparatur tersebut cukup sulit dan kompleks untuk mencapainya. Tetapi melalui sikap optimis 
yang ditumbuhkan dalam setiap proses pengembangan sumberdaya aparatur, paling tidak tahapan serta proses yang mengarah kepada proses pengembangan kapasitas aparatur pemerintah daerah harus dilalui dengan dukungan kebijakan pemangku jabatan tertinggi pemerintahan. Sehingga tujuan dapat dijadikan pegangan bagi setiap aparatur pemerintah daerah untuk saling berkompetensi secara positif yang mengarah kepada kolaborasi team.

Melihat fenomena sekarang di Indonesia untuk dapat mempersiapkan aparatur penerima tugas baru dan estafet kepemimpinan di masa datang, hendaknya Pendidikan dan pelatihan mempunyai tujuan sebagai berikut: Mengetahui tingkat pengetahuan, berupa keterampilan aparatur; untuk memperoleh informasi tentang pengembangan apa yang akan dilaksanakan; Apakah terjadi transpormasi yang diharapkan atau tidak, dengan apakah transformasi tersebut tercermin dalam pelaksanaan pekerjaan aparatur; dan tindak lanjut yang berkesinambungan, transformasi yang diharapkan dari suatu pengembangan memang terjadi dalam kurun waktu yang cukup lama dimasa depan, tidak hanya segera setelah program selesai, karena hasil dari suatu program pengembangan tidak selalu terlihat dengan segera. Mutasi dan rotasi memberikan kepastian kepada aparatur untukdiperlakukan secara wajar,dan untuk menumbuhkan kesegaran kerja, gairah kerja, agar supaya produktifitas tercapai.

Dengan kondisi aparatur yang demikian, maka baik langsung maupun tidak langsung akan meningkatkan akuntabilitas publik, karena mampu menetapkan kebijakan publik yang semakin transparan dan dapat diukur tingkat keberhasilan (performance) atas kebijakan tersebut. Fakta yang menjadi landasan utama dalam setiap pengambilan kebijakan, dan sudah menjadi kenyataan bahwa dunia pendidikan dan pelatihan Sumberdaya manusaia yang terabaikan akan berakibat krisis multidimensional yang belum juga kunjung reda sampai pada saat ini masih dialami oleh Bangsa Indonesia, dalam dunia pendidikan harus diakui kita semakin tertinggal dari dunia internasional.

Kemudian Terry dalam Moekerji (1991:21), mengemukakan bahwa materi pengembangan harus disesuaikan dengan tujuan yang hendak dicapai. Materi pendidikan pelatihan menggunakan bahan tertulis sebagai dasar instruksi, pemeriksaan dan referensi agar dengan mudah dapat dipelajari oleh peserta pendidikan dan pelatihan.Materi pendidikan dan pelatihan ada kesesuaian dengan tingkat kognisi peserta pendidikan dan pelatihan, dengan kebutuhan organisasi, dengan harapan aparatur dapat memiliki kompetensi. Kesesuain dengan inovasi materi pendidikan dan pelatihan berupa: bahan materi pendidikan dan pelatihan dilengkapi dengan referensi tambahan yang sesuai, materi pendidikan dan pelatihan selalu baru dan up to date, berorientasi menyiapkan aparatur yang berkualitas.

Untuk menghindarkan berbagai kesalahan dari kebijakan pengembangan dalam bidang pendidikan dan pelatihan seharusnya berbasis kompetensi ini diharapkan dapat menjadi pendorong (trigerting) bagi aparatur dalam memberikan pelayanan yang baik.Kompetensi aparat tersebut secara langsung dapat membantu didalam melaksanakan tugas dalam jabatan. Strategi peningkatan kompetensi aparatur melalui pendidikan dan pelatihan seyogyanya tidak dilihat secara parsial tetapi holistik. Keseluruhan unsur ini pertu di manage melalui pembuatan sistemnya, penerapan sistem tersebut secara konsisten, dan penyempurnaan yang terus-menerus terhadap sistem yang ada, guna menghasilkan sumberdaya aparatur pemerintahan yang professional

\section{SIMPULAN}

Kebijakan pendidikan dan pelatihan pelaksanaannya tidak terencana dengan 
baik dan berkesinambungan tidak nmendukung terciptanya aparatur yang berkualitas. Dan kebijakan pembinaan karier, dan pengembangan karier aparatur pemerintah daerah, tidak merujuk pada model ideal birokrasi. Hal ini menyebabkan pengambilan keputusan mengenai penempatan aparatur tidak didasarkan atas kemampuan, juga tidak sesuai dengan rekam jejak bagi aparatur, dan kehidupan organisasi yang tidak dipisahkan secara jelas dari kehidupan pribadi

\section{DAFTAR PUSTAKA}

Ahmadi Rulam. 2005. Memahami Metodolologi Penelitian KualitattifCet.I ,- Malang: Penerbit Universitas Negeri Malang.

Akhyar Efendi, 2012,JurnalNasional ManajemenPegawai NegeriSipil Efektif,Jakarta

Ashari Edy Topo, 2010,Reformasi Pengelolaan Sumberdaya Aparatur Prasyarat Tata Kelolah Birokrasi Yang Baik, dalam Jurnal Borneo Administrasi Vol.6 No.2 Tahun 2010.

Handoko, Hani T, 1995,Manajemen Personalia dan Sumberdaya Manusia, Yogyakarta: BPFEP UGM.

Keban, Yeremias T, 2008,Enam Dimensi Strategis Administrasi Publik; Konsep, Teoridan Isu.Edisi 2 Yogyakarta: Gaya Media.

Keputusan Kepala lembaga Administrasi Negara N0.193/XIII/10/6/200, tentang Pedoman Umum Pendidikan dan PelatihanPegawai Negeri Sipil

Louisiana, Jovensky, 2000dalam Haq dan Kinder 1986,Managemen Of Human
Resource, Second Edition USA: University Press Prentice Hall.

Makmur 2009,Teori Manajemen Stratejik Dalam Pemerintahan dan Pembangunan PT. Refika Aditama, Bandung

Mukijat, 1992, Analisis jabatan,Penerbit Bandung

Moekerji, 1991, Pelatihan dan Pengembangan Untuk Meningkatkan Kinerja SDM. Bandung: STIA LAN Press.

Peraturan Pemerintah Republik Indonesia No. 101 tahun 2000,,Tentang Pendidikan dan Pelatihan Jabatan Pegawai Negeri Sipil.

Peraturan Presiden Republik Indonesia Nomor 81 Tahun 2010, Tentang Grand Design ReformasiBirokrasi 2010-2025.

Peraturan Menteri Negara Pendayagunaan Aparatur Negara dan Reformasi Birokrasi Nomor 20 Tahun 2010, ${ }^{\mathrm{T}}$ entang Road Map Reformasi Birokrasi Tahun 2010- 2014.

Peraturan BKN Nomor 13 Tanggal 28 Juni 2011,Tentang Pemegang Jabatan Pegawai Negeri SipilAparatur Pemerintah

Peraturan Pemerintah No.16 Tahun 1994,Tentang Jabatan Fungsional Pegawai Negeri Sipil Presiden Republik Indonesia.

Peraturan Pemerintah No. 32 Tahun 2004,Tentang Pelaksanaan Otonomi Pemerintahan Daerah.

Rosidah, 2008,Jurnal Manajemen Pendidikan dan Pelatihan dalam Upaya optimalisasi Kinerja Pegawai Publik, Jurnal Kebijakan dan 
Administrasi Publik, Volume 8 No.

2 Tahun 2008, Jakarta.

Robbins Stephen P. 1994,Perilaku Organisasi Konsep Kontropersi dan Aplikasi (Terjemahan). Jilid I. Jakarta: Prehalindo.

Salusu, J. 1996, Pengambilan Keputusan Stratejik untuk Organisasi Publik dan Organisasi Nnon Profit. Jakarta: Gramedia widiasarana Indonesia.

Sedarmayanti, 2007, Manajemen sumberdaya manusia. reformasi birokrasi dan manajemen pegawai negeri sipil.Bandung:Aditama.

Siagian, 1987, dalam Jurnal Taufiqurrahman, Diklat dan Budaya Kerja Pegawai Negeri Sipil Jakarta.

Tamin Faisal, 2005, Pelopor Netralisasi Politik Pegawai Negeri Sipil, Penerbit MENPAN RI.

Tasrifin Muhammad, 2013, Jurnal Manajemen Karier, Naratama Bandung .

Thoha, Miftah,2007,“Birokrasi Politik Indonesia,Penerbit GrafindoPersada Jakarta.

Winarso \& Ratminto,2011,Penyusunan Sistim Perencanaan Karier Pemerintah Kabupaten Klateng Jawa Tengah, Jurnal studi pemerintahan Volume 2, Tanggal 2 Agustus 2011.
Undang -Undang No.43 Tahun 1999 Tentang Pokok-Pokok Kepegawaian.

